A N N A L E S

UNIVERSITATIS MARIAE CURIE-SKŁODOWSKA

LUBLIN - POLONIA

VOL. LXVII, 1

SECTIO G

2020

Zachodniopomorski Uniwersytet Technologiczny w Szczecinie

MACIEJ JACEK NOWAK

maciej.nowak@zut.edu.pl

ORCID: 0000-0001-6437-3226

\title{
Interes publiczny w systemie gospodarki przestrzennej
}

Public Interest in the Spatial Management System

\section{WPROWADZENIE}

Doprecyzowanie ram systemu gospodarki przestrzennej stanowi zadanie istotne z perspektywy różnych dyscyplin. Ważna w tym kontekście jest m.in. zarówno perspektywa prawna, jak i związana z naukami o polityce publicznej. Wśród kluczowych uwarunkowań znajdują się podstawy aksjologiczne całego systemu. To do nich powinny być dostosowane funkcje narzędzi polityki przestrzennej. Również one w wymiarze prawnym powinny stanowić swoistą podstawę przy dokonywaniu wykładni przepisów.

W tym kontekście doprecyzowania wymaga ujęcie interesu publicznego w systemie gospodarki przestrzennej (w kontekście związanym z ochroną ładu przestrzennego). Wiąże się ono znacząco z zasadą ochrony walorów terenu uwzględniających ład przestrzenny (a w uproszczeniu - z zasadą ochrony ładu przestrzennego). Tak naprawdę kwestie związane $\mathrm{z}$ interesem publicznym znacząco powinny więc przesądzać o realnym zakresie możliwego zagospodarowania terenu. W wielu wypadkach jednak praktyka ukształtowała się nieco odmiennie.

Celem artykułu jest określenie roli, jaką pojęcie interesu publicznego powinno odgrywać w systemie gospodarki przestrzennej oraz przy wykładni przepisów związanych z planowaniem przestrzennym, w kontekście obejmującym ochronę i kształtowanie ładu przestrzennego. Opierając się na ujętym w ustawie o planowaniu i zagospodarowaniu przestrzennym ujęciu interesu publicznego, zweryfikowano jego realne zastosowanie $\mathrm{w}$ ramach polityki publicznej (której polityka przestrzenna jest jedną z nieodłącznych części składowych). 


\section{INTERES PUBLICZNY W USTAWIE O PLANOWANIU I ZAGOSPODAROWANIU PRZESTRZENNYM}

Zgodnie z art. 2 pkt 4 ustawy z dnia 27 marca 2003 r. o planowaniu i zagospodarowaniu przestrzennym ${ }^{1}$ przez interes publiczny należy rozumieć uogólniony cel dążeń i działań, uwzględniających zobiektywizowane potrzeby ogółu społeczeństwa lub lokalnych społeczności, związanych z zagospodarowaniem przestrzennym. Nie budzi wątpliwości, że przedmiotowe pojęcie zostało ujęte w sposób ogólny (pojawiają się nawet zarzuty, że zbyt ogólny). Uwzględnia ono perspektywę ogółu społeczeństwa (rozumianą w kontekście różnych skal terytorialnych) oraz ich interes, dążenie do określonego zagospodarowania danego terenu. O ogólnym kierunku jego zagospodarowania przesądza fakt, że naczelną wartością w systemie gospodarki przestrzennej ustawodawca uczynił ład przestrzenny, rozumiany jako (art. 2 pkt 1 ustawy) takie ukształtowanie przestrzeni, które tworzy harmonijną całość oraz uwzględnia w uporządkowanych relacjach wszelkie uwarunkowania i wymagania funkcjonalne, społeczno-gospodarcze, środowiskowe, kulturowe oraz kompozycyjno-estetyczne. Również to pojęcie ma charakter ogólny. W kontekście dokonywanej wykładni przepisów można stosować je więc w ograniczonym stopniu (np. odmowy wydania konkretnej decyzji administracyjnej nie można uzasadniać tylko i wyłącznie tym, że w ocenie organu określone zamierzenie budowlane jest sprzeczne z ładem przestrzennym). $\mathrm{Z}$ drugiej strony jednak błędne jest zupełne ignorowanie zasady ładu przestrzennego. Ma ona - jak wskazuje A. Brzezińska-Rawa - wraz ze zrównoważonym rozwojem pierwszorzędną rangę jako zasada planowania przestrzennego².

Ignorowanie tej zasady ma miejsce $\mathrm{w}$ praktyce dosyć często. Z przeprowadzonych badań wynika, że w przeważającej części gmin ład przestrzenny nie jest uważany (przez organy i osoby odpowiedzialne za stosowanie narzędzi polityki przestrzennej) za kluczową wartość w systemie gospodarki przestrzennej³. Przekłada się to na zbyt szerokie umożliwianie realizacji uznaniowej zabudowy, a w konsekwencji - na poszerzanie chaosu przestrzennego. To ostatnie ma wymiar nie tylko estetyczny, ponieważ chaos przestrzenny determinuje znaczące straty, w tym o charakterze ekonomicznym i społecznym ${ }^{4}$.

1 Dz.U. nr 80, poz. 717 ze zm.

2 A. Brzezińska-Rawa, Spójność i ciagłość podstawowych aktów planowania przestrzennego, Toruń 2019, s. 57.

3 M. Nowak, Niesprawność władz publicznych a system gospodarki przestrzennej, „Studia Komitetu Przestrzennego Zagospodarowania Kraju PAN" 2017, t. 175, s. 181. Bardzo często kwestiom związanym $\mathrm{z}$ ładem przestrzennym przeciwstawia się prawo własności. W tym miejscu można zaznaczyć, że przedmiotem osobnej dyskusji może być realny zakres tego prawa i np. kwestia ujęcia w nim prawa do zabudowy.

4 Koszty chaosu przestrzennego, red. A. Kowalewski, T. Markowski, P. Śleszyński, „Studia Komitetu Przestrzennego Zagospodarowania Kraju PAN"2018, t. 182(2), s. 7. 
Biorąc pod uwagę powyższe kwestie, należy jednoznacznie wskazać, że interes publiczny powiązany jest nieodłącznie w systemie gospodarki przestrzennej z kwestią ochrony ładu przestrzennego ${ }^{5}$ (bezpośredniemu powiązaniu tych pojęć sprzyja też wielowymiarowy charakter ładu przestrzennego). Nie tylko z perspektywy funkcjonalnej, lecz także z perspektywy dokonywania wykładni przepisów występuje konieczność szerszego uwzględnienia kwestii związanych z interesem publicznym i ładem przestrzennym. Aby było to możliwe, konieczne jest sprecyzowanie tych pojęć z perspektywy urbanistyczno-ekonomicznej. Dopiero takie ujęcie będzie można adaptować do perspektywy prawnej.

W tym miejscu należy podkreślić ujęcie interesu publicznego z perspektywy wykładni prawnej. W niniejszym artykule kwestie związane ze szczególnymi sposobami ujęcia interesu publicznego nie zostały uwzględnione, opracowanie koncentruje się bowiem na ujęciu powyższych kwestii z perspektywy polityki przestrzennej (oraz konkretnych, związanych z nią problemów systemowych). Warto jednak powołać tezy M. Woźniak, która w bogatych rozważaniach stara się również odpowiedzieć na kluczowe z perspektywy niniejszego tekstu pytanie, w jaki sposób interes publiczny wyznacza granice prawa do zagospodarowania terenów. Autorka podkreśla, że interes publiczny jest zawarty w wartościach wyróżnionych w art. 1 ust. 2 ustawy o planowaniu i zagospodarowaniu przestrzennym i w praktyce jego ujęcie sprowadza się do permanentnego wartościowania interesów w konkretnych sytuacjach ${ }^{6}$. Z perspektywy zwłaszcza realizacyjnej polityki przestrzennej problemem (a także determinantą niesprawności władz publicznych) pozostaje określenie w miarę precyzyjnego katalogu tego typu sytuacji. Przy ich wyodrębnianiu (w dalszej części artykułu) warta podkreślenia jest teza, że każda ingerencja w sposób wykonywania prawa własności musi mieścić się w granicach wyznaczonych interesem publicznym ${ }^{7}$.

Ochrona ładu przestrzennego powinna znajdować odzwierciedlenie przy stosowaniu poszczególnych narzędzi polityki przestrzennej. W pierwszej kolejności należy zwrócić uwagę na studia uwarunkowań i kierunków zagospodarowania przestrzennego oraz miejscowe plany zagospodarowania przestrzennego ${ }^{8}$. O stworzeniu podstaw do szerszej ochrony ładu przestrzennego (czy to z perspek-

5 A właściwie ochroną walorów związanych z ładem przestrzennym. Ład przestrzenny to bowiem stan idealnego zagospodarowania przestrzeni, który rzecz jasna nigdy nie wystąpi, ale do którego należy w możliwie najszerszym stopniu się zbliżać.

6 M. Woźniak, Interes publiczny $i$ interes indywidualny $w$ planowaniu i zagospodarowaniu przestrzennym, Opole 2018, s. 158-159.

7 T. Bąkowski, Prawne problemy rozpraszania i koncentracji zabudowy, Gdańsk 2018, s. 20.

8 K. Rokicka-Murszewska, Administracyjnoprawne aspekty opłaty planistycznej, Toruń 2019, s. 46-52. Nie należy w tym kontekście uwzględniać decyzji o warunkach zabudowy i zagospodarowania terenu. Zob. M. Nowak, Decyzje o warunkach zabudowy i zagospodarowania terenu - instrument czy wytacznie bariera rozwoju?, „Studia Regionalne i Lokalne” 2012, nr 2, s. 77-91. 
tywy wyższej hierarchicznie, czy to z perspektywy sektorowej) można mówić również w kontekście stosowania takich narzędzi, jak plany zagospodarowania przestrzennego województwa, koncepcja przestrzennego zagospodarowania kraju, audyt krajobrazowy czy strategiczna ocena oddziaływania na środowisko. W przypadku stosowania narzędzi bardziej sektorowych bardziej adekwatne byłoby sformułowanie, że chodzi o ochronę wybranych aspektów związanych $\mathrm{z}$ ładem przestrzennym. Poprawne z perspektywy formalnoprawnej stosowanie wszystkich wymienionych narzędzi jednak nie gwarantuje kompleksowej ochrony, dlatego konieczna jest weryfikacja tego zagadnienia z perspektywy urbanistycznej oraz realizacji polityki publicznej.

\section{INTERES PUBLICZNY I ŁAD PRZESTRZENNY W UJĘCIU URBANISTYCZNYM}

Kluczowe z perspektywy analizowanej problematyki interesu publicznego w polityce publicznej ujęcie analizowanej kwestii zostało przedstawione przez T. Markowskiego. Przyjął on następujące założenia:

- w przestrzeni realizuje się podstawowe prawo do sprawiedliwego dostępu do podstawowych dóbr,

- zawłaszczanie przestrzeni przez właścicieli nieruchomości i innych jej użytkowników powoduje, że dobra publiczne nie są równo dostępne,

- interes publiczny powinien być rozumiany jako działanie władz publicznych na rzecz zapewnienia praw do równego traktowania lub tworzenia równych szans członkom społeczeństwa,

- interes publiczny może być powiązany z polityką ex ante polegającą na tworzeniu na rzecz jednostek równych szans, a jednocześnie z polityką ex post, wyrównującą nierówności społeczne,

- w konsekwencji należy przyjąć, że interes publiczny, który będzie związany z zagospodarowaniem przestrzeni, musi znaleźć swoje prawne odniesienie $\mathrm{w}$ ustawie dotyczącej planowania i zagospodarowania przestrzennego, a także w wiążących planach zagospodarowania przestrzennego9.

Ten punkt widzenia znajduje pełne odzwierciedlenie w innych ujęciach kwestii interesu publicznego. Jak słusznie podkreślił H. Izdebski, w celu ochrony ładu przestrzennego za kluczową uznać należy aktywność władzy publicznej ukierunkowaną na realizację interesu publicznego w procesach zagospodarowania

9 T. Markowski, Teoria sprawiedliwości i interes publiczny jako podstawa budowania regulacyjnego systemu planowania przestrzennego: konceptualizacja problemu, [w:] Badania miejskie i regionalne. Doświadczenia i perspektywy, red. F. Kuźnik, „Studia Komitetu Przestrzennego Zagospodarowania Kraju PAN" 2013, t. 153, s. 13-18. 
zwłaszcza gruntów prywatnych ${ }^{10}$. Wymaga to szerszego doprecyzowania realnych ram i potrzeb związanych $z$ ładem przestrzennym, podejmowanych wielokrotnie w literaturze przedmiotu. Z kolei K. Kuciński uznał, że dbałość o zagospodarowanie przestrzeni $\mathrm{w}$ zgodzie $\mathrm{z}$ ładem przestrzennym obejmuje logikę przestrzenną, czytelność przestrzenną, walory środowiska przyrodniczego (w tym ich zdolność regenerowania się i zaspokajania odnawiających się potrzeb ludzkich), optymalizację przemieszczeń osób, dóbr i informacji, piękno otoczenia, racjonalny współczynnik ekologiczny oraz optymalną relację między centrum a obszarami peryferyjnymi ${ }^{11}$. Poniżej podane kryteria należy uznać za ważne również przy okazji analizy regulacji prawnych, w szczególności (jak na dalszym etapie rozważań zostanie to wskazane) podstaw dla uzasadnionych ograniczeń możliwości zagospodarowania terenu ujętych w miejscowych planach zagospodarowania przestrzennego. Jest to ważne z perspektywy władz publicznych, zwłaszcza tych, którym zależy na ochronie ładu przestrzennego (i właśnie w tym kontekście na uwzględnianiu interesu publicznego). Jako problem, a nawet pewną barierę, należy wskazać w tym kontekście niedookreśloność powołanych wyżej tez, zgodnie z którymi w systemie gospodarki przestrzennej konkretyzacja interesu publicznego zależy od konkretnych, szczegółowych przypadków. Rozumiejąc status prawny pojęcia „,interes publiczny”, trzeba uznać, że z perspektywy realizacyjnej jest to ujęcie wciąż niewystarczające. Dowodem na to są wyniki badań A. Zawadzkiej, które wykazały, że władze gminne, uchwalając miejscowe plany zagospodarowania przestrzennego, posługują się bardzo zróżnicowanym (wzajemnie sprzecznym, niejasnym, czasem nader ogólnikowym) rozumieniem tego, czym są obligatoryjne dla tych planów zasady ochrony i kształtowania ładu przestrzennego ${ }^{12}$.

Za równie istotne $\mathrm{w}$ tym kontekście należy uznać uwagi poczynione przez P. Śleszyńskiego. Autor określił i wyodrębnił wskaźniki zagospodarowania i ładu przestrzennego $\mathrm{w}$ gminach. Ich zastosowanie może służyć też do próby konkretyzacji pojęcia ładu przestrzennego w lokalnych politykach przestrzennych. W związku z powyższym autor wyodrębnił wskaźniki: osadniczo-infrastrukturalne, społeczno-ekonomiczne (np. warunki mieszkaniowe, dostępność przestrzenna, uwarunkowania inwestycyjne), przyrodnicze i ochrony środowiska (np. jakość życia, fragmentacja krajobrazu, ochrona środowiska), funkcjonalne (udział terenów o danej funkcji w powierzchni ogólnej, różnorodność funkcji użytkowania, potencjalna kolizyjność funkcji) oraz prawno-urbanistyczne (czyli pokrycie planistyczne terenów miejscowymi planami zagospodarowania przestrzennego) ${ }^{13}$.

${ }^{10}$ H. Izdebski, Ideologia i zagospodarowanie przestrzeni, Warszawa 2013, s. 139.

11 K. Kuciński, Geografia ekonomiczna, Kraków 2009, s. 55-56.

12 A. Zawadzka, Ład nasz przestrzenny, Gdańsk-Warszawa 2017, s. 95-98.

13 P. Śleszyński, Wskaźniki zagospodarowania i ładu przestrzennego w gminach, „Biuletyn Komitetu Przestrzennego Zagospodarowania Kraju PAN” 2013, z. 252, s. 180-182. 
Również ten zakres informacji konkretyzujących kwestię ładu przestrzennego powinien w szerszej niż obecnie skali zostać włączony do lokalnej polityki przestrzennej i znajdować np. bezpośrednie przełożenie na prowadzone na szczeblu gminy analizy przygotowywane przed sporządzeniem miejscowych planów zagospodarowania przestrzennego oraz cykliczne analizy, w ramach których weryfikuje się sytuację planistyczną gminy (co w obu przypadkach stanowić będzie podstawę do przełożenia na konkretne normy planistyczne). Badania potwierdzają zresztą tezę, że wpływ narzędzi polityki przestrzennej na ład przestrzenny powinien być oceniany nie tylko z perspektywy prawnej, lecz także np. geograficznej, czego wyrazem może być analiza cech morfometrycznych planów ${ }^{14}$.

Charakterystykę uwarunkowań dotyczących szerszego wymiaru interesu publicznego i ładu przestrzennego warto uzupełnić o jeszcze jedno spostrzeżenie. Jak wskazuje M. Woźniak, szczególnej analizie należy poddawać przypadki konfliktów przestrzennych, ponieważ to wówczas dochodzi do realnych antagonizmów pomiędzy interesem publicznym a interesem prywatnym ${ }^{15}$. Rozwijając niniejszy punkt widzenia, warto zauważyć, że pojęcie konfliktów przestrzennych w języku prawniczym występuje w ograniczonym stopniu. Z perspektywy polityki publicznej jest inaczej - konflikty przestrzenne stanowią bowiem zarówno kluczowy punkt odniesienia dla ochrony ładu przestrzennego, jak i sytuację, na którą muszą zwracać szczególną uwagę organy administracji publicznej przy okazji prowadzenia polityki przestrzennej. Nie w każdym przypadku konfliktu przestrzennego występuje bezpośredni antagonizm pomiędzy interesem publicznym a interesem prywatnym - w niektórych chodzi o doprecyzowanie priorytetów w ramach interesu publicznego. Niemniej rzeczywiście to na tym etapie dochodzi do realnego (choć niewyrażonego wprost ustawowo) zastosowania interesu publicznego. Czynnikiem blokującym jego ochronę przy stosowaniu poszczególnych narzędzi polityki przestrzennej jest niesprawność władz publicznych - na szczeblu centralnym (sprowadzająca się do nieumiejętnego ujęcia i ochrony określonych wartości w regulacjach prawnych) oraz na szczeblu lokalnym (związana ze zróżnicowanym wdrażaniem poszczególnych instytucji - jednym z jej przejawów może być brak przywiązania dostatecznej wagi do ładu przestrzennego $\mathrm{w}$ gminach) ${ }^{16}$.

${ }^{14}$ P. Śleszyński, M. Stępniak, D. Mazurek, Oszacowanie skutków presji inwestycyjnej $i$ nadpodaży gruntów budowlanych $w$ strefie podmiejskiej Warszawy na przykładzie gmin pasma zachodniego, „Przegląd Geograficzny” 2018, nr 2, DOI: https://doi.org/10.7163/PrzG.2018.2.2, s. 233-234; W. Izdebski, P. Śleszyński, Z. Malinowski, M. Kursa, Analiza morfometryczna planów miejscowych w Polsce, „Infrastruktura i Ekologia Terenów Wiejskich” 2018, nr 2(1), s. 331-340.

${ }_{15}$ M. Woźniak, Interes publiczny jako przesłanka działań organów planistycznych, [w:] Przestrzeń i nieruchomość jako przedmiot prawa administracyjnego. Publiczne prawo rzeczowe, red. I. Niżnik-Dobosz, Warszawa 2011, s. 90-92.

16 A. Zybała, Polityka przestrzenna i jej rezultaty w warunkach rosnącej złożoności jej problemów, „Studia z Polityki Publicznej” 2019, nr 2, DOI: https://doi.org/10.33119/KSzPP/2019.2.5, 


\section{SPOSOBY POSZERZANIA ROLI INTERESU PUBLICZNEGO PRZY WYKŁADNI NORM PRZESTRZENNYCH}

Wydawać by się mogło, że kluczowym środkiem poszerzającym rolę (ochronę) interesu publicznego może być zmiana przepisów dotyczących planowania i zagospodarowania przestrzennego. Tymczasem, mimo licznych analiz ${ }^{17}$ i nawet ministerialnych propozycji zmian, reforma systemu gospodarki przestrzennej wciąż stoi pod znakiem zapytania. Co więcej, można zauważyć tendencję, w ramach której nieznaczne zmiany (nawet wdrażane $\mathrm{z}$ dobrą intencją) podlegają następnie w praktyce odmiennej wykładni ${ }^{18}$. Dlatego za kluczowy element właśnie z perspektywy dokonywanej wykładni należy uznać szersze uwzględnianie interesu publicznego i ładu przestrzennego, co zresztą spotyka się z aprobatą doktryny ${ }^{19}$.

Doprecyzowania wymaga jednak ustalenie, na czym konkretnie powinno to polegać. Należy w tym przypadku oprzeć się na następujących założeniach:

- uwzględnienie kwestii związanej z interesem publicznym i ładem przestrzennym przy wykładni przepisów związanych z planowaniem i zagospodarowaniem przestrzennym jest konieczne,

- wykładnia taka nie może prowadzić do wniosków arbitralnych i zupełnie uznaniowych,

- w przedmiotowej sytuacji (aby pogodzić oba wskazane powyżej stwierdzenia) realnym punktem odniesienia może czy wręcz musi być literatura urbanistyczno-geograficzna, w której kwestie związane z ładem przestrzennym są w miarę możliwości konkretyzowane,

- niezależnie od powyższego można wskazać również kilka przepisów i instytucji, w których w obecnym zakresie wykładnia w znikomym stopniu uwzględnia kwestie związane z interesem publicznym i ładem przestrzennym.

Szczegółowy kontekst związany z uwzględnianiem interesu publicznego i ładu przestrzennego przy wykładni przepisów można odnieść do następujących (kluczowych z punktu widzenia realizacji polityki publicznej) instytucji ustawy o planowaniu i zagospodarowaniu przestrzennym:

1. Analizy w zagospodarowaniu przestrzennym. Są wymagane zarówno cykliczne, jak i przed sporządzeniem czy zmianą studiów uwarunkowań

\footnotetext{
s. 103-122; D. Drzazga, Systemowe uwarunkowania planowania przestrzennego jako instrument osiagania sustensywnego rozwoju, Łódź 2019, s. 47-54.

${ }_{17}$ A. Kowalewski, Interes publiczny i przestrzeń - kilka uwag, [w:] Zarzadzanie rozwojem współczesnych miast, red. J. Danielewicz, D. Sikora-Fernandez, Łódź 2019, s. 276.

18 A. Kowalewski, M. Nowak, Chaos przestrzenny i prawo. Uwarunkowania, procesy, skutki, rekomendacje, „Studia Komitetu Przestrzennego Zagospodarowania Kraju PAN” 2018, t. 182(1), s. 92-102.

19 Z. Leoński, M. Szewczyk, M. Kruś, Prawo zagospodarowania przestrzeni, Warszawa 2012, s. 50-52.
} 
i kierunków zagospodarowania przestrzennego oraz miejscowych planów zagospodarowania przestrzennego. Rola analiz w procesie planowania przestrzennego jest $\mathrm{w}$ coraz szerszym zakresie podkreślana przez ustawodawcę. Praktyka w skali lokalnej zbyt często jednak sprowadza te analizy do krótkich, ograniczonych informacji, dających znikomy obszar uwarunkowań i realiów przestrzennych (albo uwzględniających perspektywę jedynie lokalną, a czasem wręcz interesy indywidualne, grupowe, ale już nie interes publiczny). Zmiana w tym zakresie powinna sprowadzać się do znacznie szerszego zaakcentowania roli ładu przestrzennego w ramach analiz. Nie chodzi jedynie o potwierdzenie tej roli, lecz o szczegółowe odniesienie się do wskaźników zagospodarowania i ładu przestrzennego. Ich szersze uwzględnienie prowadzić będzie do uzasadnionej ingerencji w narzędziach polityki przestrzennej w sposób zagospodarowania terenu. Będzie to też podstawa do uwzględnienia $w$ regulacjach związanych z planowaniem i zagospodarowaniem przestrzennym tak ważnej perspektywy urbanistyczno-geograficznej. $Z$ jednej strony powyższe obejmuje więc kwestie związane z wykładnią przepisów, a z drugiej wymaga czegoś jeszcze - zdecydowanej determinacji i ukierunkowania władz publicznych.

2. Zakres miejscowego planu zagospodarowania przestrzennego. Pomijając kwestie wskazane w pkt 1, warto podkreślić jeszcze jeden element. Zgodnie z art. 15 ust. 2 pkt 2 ustawy o planowaniu i zagospodarowaniu przestrzennym obligatoryjnym elementem miejscowego planu zagospodarowania przestrzennego są ,zasady ochrony i kształtowania ładu przestrzennego". W wielu wypadkach podmioty sporządzające mają problem, jak należy określać te (kluczowe przecież z perspektywy systemu gospodarki przestrzennej) kwestie, co w konsekwencji prowadzi do błędów (np. do powielania szczegółowych zasad zagospodarowania terenu). Natomiast przedmiotowe zasady powinny być sformułowane ogólnie, opierać się na przeprowadzonych analizach i wskazywać kluczowe problemy związane z ładem przestrzennym wraz z kierunkami ich rozwiązań (które na dalszym etapie mają zostać skonkretyzowane). W takim zróżnicowaniu również kluczowa wydaje się determinacja władz publicznych w zakresie realizacji odpowiednio ukierunkowanej (na ochronę ładu przestrzennego) polityki przestrzennej.

3. Decyzja o warunkach zabudowy. W literaturze występuje zróżnicowana opinia w przedmiocie tego, czy można tę instytucję w ogóle uznać za „narzędzie polityki przestrzennej”. Zgodnie z przeważającą oceną urbanistyczną przesłanki związane z wydaniem tej decyzji generują chaos przestrzenny. Podzielając ten punkt widzenia, należy jednak wskazać, że nie może to prowadzić do uchybienia zasady racjonalnego ustawodawcy przy dokonywaniu wykładni. O ile sam ład przestrzenny nie może stanowić 
podstawy do odmowy ustalenia warunków zabudowy, o tyle racje z nim związane mogą stanowić w trakcie postępowań barierę dla negatywnych praktyk, w szczególności dla powiększania obszaru analizowanego tylko i wyłącznie w takim celu, aby objąć nim określoną zabudowę i tym samym doprowadzić do wydania pozytywnej decyzji.

4. Inwestycje celu publicznego. Wyrażone w ustawie o planowaniu i zagospodarowaniu przestrzennym pod względem terminologicznym najszerzej nawiązują do kwestii związanych z interesem publicznym. Trzeba w tym miejscu jednoznacznie podkreślić, że nie określają one wyłącznego zakresu zastosowania interesu publicznego w planowaniu przestrzennym. Pewnym problemem, odwracającym uwagę od kluczowej kwestii, jest - oparte na niejasnych regulacjach i nieco zbyt subiektywnej wykładni - rozróżnianie zakresu tych inwestycji. Rolą władz publicznych jest odpowiednie wyodrębnienie, sklasyfikowanie tych inwestycji, a następnie określenie ich lokalizacji.

Wyodrębnienie powyższych punktów jest ważne nie tylko z perspektywy samej wykładni przepisów, lecz także z perspektywy realizacji poszczególnych polityk przestrzennych. Trzeba więc przyjąć, że polityka przestrzenna (w szczególności realizowana na szczeblu gminy) ukierunkowana na szersze uwzględnienie (wdrożenie) zagadnień powiązanych z interesem publicznym (ułatwiających jego konkretyzację) poza samym wymiarem jakościowym aktów planistycznych powinna sprowadzać się do:

- rozwiniętych analiz uwarunkowań (i stanu zmian) zagospodarowania przestrzennego. Chodzi o zakres tych analiz (opartych na przepisach ustawowych) znacznie szerszy niż obecnie,

- bardziej rygorystycznej niż obecnie wykładni z perspektywy możliwości zagospodarowania terenu na podstawie aktów planistycznych, uwzględniającej ograniczenia związane z ochroną walorów ładu przestrzennego,

- zrównoważonego planowania lokalizacji inwestycji celu publicznego.

\section{PODSUMOWANIE}

Interes publiczny w systemie gospodarki przestrzennej jest nieodłącznie powiązany z ładem przestrzennym i jego ochroną. W niniejszym artykule określono warianty, dzięki którym - w ramach obecnego systemu - można (i należy) próbować poszerzać rolę wskazanych instytucji. Biorąc pod uwagę wyniki licznych analiz, można dodać, że nie będzie to wystarczające. Przedmiotowe rozwiązanie stanowi jeden z koniecznych elementów, ale niezależnie od perspektywy prawnej należy dbać również o inne, w tym o podwyższanie poziomu kapitału społecznego zarówno w skali lokalnej, jak i ponadlokalnej. Niemniej przynajmniej część rekomendowanych działań będzie z powyższym znacząco skorelowana. 


\section{BIBLIOGRAFIA}

\section{LITERATURA}

Bąkowski T., Prawne problemy rozpraszania i koncentracji zabudowy, Gdańsk 2018.

Brzezińska-Rawa A., Spójność i ciagłość podstawowych aktów planowania przestrzennego, Toruń 2019.

Drzazga D., Systemowe uwarunkowania planowania przestrzennego jako instrument osiagania sustensywnego rozwoju, Łódź 2019.

Izdebski H., Ideologia i zagospodarowanie przestrzeni, Warszawa 2013.

Izdebski W., Śleszyński P., Malinowski Z., Kursa M., Analiza morfometryczna planów miejscowych w Polsce, „Infrastruktura i Ekologia Terenów Wiejskich” 2018, nr 2(1).

Koszty chaosu przestrzennego, red. A. Kowalewski, T. Markowski, P. Śleszyński, „Studia Komitetu Przestrzennego Zagospodarowania Kraju PAN" 2018, t. 182(2).

Kowalewski A., Interes publiczny i przestrzeń - kilka uwag, [w:] Zarządzanie rozwojem współczesnych miast, red. J. Danielewicz, D. Sikora-Fernandez, Łódź 2019.

Kowalewski A., Nowak M., Chaos przestrzenny i prawo. Uwarunkowania, procesy, skutki, rekomendacje, „Studia Komitetu Przestrzennego Zagospodarowania Kraju PAN” 2018, t. 182(1).

Kuciński K., Geografia ekonomiczna, Kraków 2009.

Leoński Z., Szewczyk M., Kruś M., Prawo zagospodarowania przestrzeni, Warszawa 2012.

Markowski T., Teoria sprawiedliwości i interes publiczny jako podstawa budowania regulacyjnego systemu planowania przestrzennego: konceptualizacja problemu, [w:] Badania miejskie i regionalne. Doświadczenia i perspektywy, red. F. Kuźnik, „Studia Komitetu Przestrzennego Zagospodarowania Kraju PAN” 2013, t. 153.

Nowak M., Decyzje o warunkach zabudowy i zagospodarowania terenu - instrument czy wytacznie bariera rozwoju?, „Studia Regionalne i Lokalne” 2012, nr 2.

Nowak M., Niesprawność władz publicznych a system gospodarki przestrzennej, „Studia Komitetu Przestrzennego Zagospodarowania Kraju PAN" 2017, t. 175.

Rokicka-Murszewska K., Administracyjnoprawne aspekty opłaty planistycznej, Toruń 2019.

Śleszyński P., Wskaźniki zagospodarowania i ładu przestrzennego w gminach, „Biuletyn Komitetu Przestrzennego Zagospodarowania Kraju PAN” 2013, z. 252.

Śleszyński P., Stępniak M., Mazurek D., Oszacowanie skutków presji inwestycyjnej i nadpodaży gruntów budowlanych w strefie podmiejskiej Warszawy na przykładzie gmin pasma zachodniego, „Przegląd Geograficzny” 2018, nr 2, DOI: https://doi.org/10.7163/PrzG.2018.2.2.

Woźniak M., Interes publiczny $i$ interes indywidualny $w$ planowaniu i zagospodarowaniu przestrzennym, Opole 2018.

Woźniak M., Interes publiczny jako przesłanka działań organów planistycznych, [w:] Przestrzeń $i$ nieruchomość jako przedmiot prawa administracyjnego. Publiczne prawo rzeczowe, red. I. Niżnik-Dobosz, Warszawa 2011.

Zawadzka A., Ład nasz przestrzenny, Gdańsk-Warszawa 2017.

Zybała A., Polityka przestrzenna i jej rezultaty w warunkach rosnącej złożoności jej problemów, „Studia z Polityki Publicznej” 2019, nr 2, DOI: https://doi.org/10.33119/KSzPP/2019.2.5.

\section{AKTY PRAWNe}

Ustawa z dnia 27 marca 2003 r. o planowaniu i zagospodarowaniu przestrzennym (Dz.U. nr 80, poz. 717 ze zm.). 


\section{SUMMARY}

The purpose of the article was to determine the role of public interest in the spatial management system. For this purpose, the perspective of two disciplines was used: law and public policy. It was pointed out that public interest in the spatial management system must be inextricably linked to spatial order. This perspective is currently not sufficiently taken into account when interpreting the provisions related to spatial planning. The article indicates provisions that require special emphasis in the context of the implementation of spatial policy associated with care for the protection of the public interest.

Keywords: public interest; spatial management system; spatial order

\section{STRESZCZENIE}

Celem artykułu było określenie roli interesu publicznego w systemie gospodarki przestrzennej. Do jego zrealizowania wykorzystano perspektywę dwóch dyscyplin: prawa i polityki publicznej. Wskazano, że interes publiczny w systemie gospodarki przestrzennej musi być nieodłącznie powiązany $\mathrm{z}$ ładem przestrzennym. Ta perspektywa nie jest obecnie wystarczająco uwzględniana przy wykładni przepisów związanych z planowaniem i zagospodarowaniem przestrzennym. W artykule wskazano przepisy wymagające szczególnego podkreślenia w kontekście realizacji polityki przestrzennej powiązanej z dbałością o ochronę interesu publicznego.

Słowa kluczowe: interes publiczny; system gospodarki przestrzennej; ład przestrzenny 